\title{
Effects of modifications to retain protozoa in continuous-culture fermenters on ruminal fermentation, microbial populations, and microbial biomass assessed by two different methods
}

\author{
I. Cabeza-Luna, M.D. Carro, J. Fernández-Yepes, E. Molina-Alcaide
}

\begin{abstract}
A B S T R A C T
An important limitation of continuous-culture fermenters is their inability of maintaining microbial populations similar to those observed in the rumen, especially protozoa numbers, which usually decrease markedly or even disappear. Two approaches (a polyurethane-sponge (SP) and a filter system (FIL) for additionally retaining protozoa were tested in continuous culture system already designed to retain protozoa (Muetzel et al., 2009), and their effects on microbial populations, fermentation parameters and microbial biomass were assessed. Two 14-day incubation runs were carried out with 6 fermenters, and in each run two fermenters were randomly assigned to each of the experimental treatments (control, SP and FIL). Total protozoa numbers assessed by microscopic counting were 1.7 and 2.1 times greater in SP and FIL fermenters than in control ones on day 14 , although differences did not reach the significance level $(P=0.855)$. Protozoal DNA concentration on day 14 were 1.6 and 1.4 times greater in SP and FIL fermenters, respectively, than in control ones, but differences were not significant $(P=0.524)$. Results from protozoal DNA concentrations determined in each fermenter on the different sampling days $(n=48)$ were positively correlated $(P<0.001)$ with the numbers of total $(\mathrm{r}=0.826)$, entodiniomorphid $(\mathrm{r}=0.824)$ and holotrich $(\mathrm{r}=0.675)$ protozoa determined by microscopic counting, indicating that both methods are valid to assess protozoa populations. The proportion of holotrich in FILfermenters was relatively constant over the incubation period (ranging from 10.5 to $13.3 \%$ of total protozoa), but decreased with time in control (from $10.9 \%$ at day 2 to $6.7 \%$ at day 14) and SP (from 10.9 to 6.9\%) fermenters. Neither the bacterial DNA concentration nor the relative abundance of fungal and archaeal DNA were influenced by any of the modifications tested, but values changed over the sampling period (days 10-14). Bacterial DNA concentration increased $(P<0.001)$ from day 10 to 14 in all fermenters, whereas the relative abundance of fungal and archaeal DNA decreased $(P<0.001)$. The tested modifications did not affect $(P>0.05)$ fermentation parameters, which reached a steady-state after 6 days of incubation. Values of microbial biomass determined using purine bases as a microbial marker were significantly correlated with the amount of bacterial plus protozoal DNA ( $\mathrm{r}=0.794 ; P=0.002 ; \mathrm{n}=12)$ in each
\end{abstract}

\footnotetext{
Abbreviations: ADFom, acid detergent fiber expressed exclusive of residual ash; aNDFom, neutral detergent fiber with heat-stable amylase and expressed exclusive of residual ash; CON, control treatment (fermenters without modification); CP, crude protein; EE, ether extract; FIL, fermenters provided with a filter system; PCA, principal component analysis; $\mathrm{PB}$, purine bases; $\mathrm{SP}$, fermenters provided with a polyurethane-sponge; VFA, volatile fatty acids
} 
fermenter. In conclusion, the two tested modifications increased the protozoa numbers in continuous-culture fermenters, and the FIL allowed maintaining a proportion of holotrich protozoa similar to that in the ruminal fluid used as inoculum.

\section{Introduction}

In vitro rumen simulation techniques such as fermenters are useful tools for the study of rumen fermentation, as they involve the use of a lower number of fistulated animals than in vivo studies, and allow performing experiments under stable and controlled conditions difficult to achieve in vivo. Ideally, the composition of the microbial populations in the fermenters should be representative, in terms of diversity and quantity, of that found in the rumen of the host animal (Mateos et al., 2015). However, a drastic decrease of protozoa over the incubation period or even a complete disappearance, in some cases, has been consistently reported in different types of fermenters (Mansfield et al., 1995; Moumen et al., 2009; Hristov et al., 2012). This effect has mainly been attributed to the washing out of protozoa from fermenters and to the exposure of fermenters contents to atmospheric oxygen (Hillman et al., 1991; Mansfield et al., 1995). Holotrich protozoa seem to be especially vulnerable to washing, and they can be cultivated for shorter periods in vitro compared to entodiniomorphid protozoa (Williams, 1986). In addition, information on the evolution of other microbial populations in fermenters over the incubation period is still scarce.

Different approaches to maintain protozoa populations in several types of fermenters have been assessed, such as to improve physical conditions for protozoa sequestration using sponge cubes in a modified semi-continuous Rusitec system (Abe and Kurihara, 1984) or filters in a dual-flow continuous fermenter (Karnati et al., 2009), decreasing the amount of diet supplied and/or the stirring speed in a dual-flow continuous fermenter (Broudiscou et al., 1997) or the use of different turnover rates for solids and liquids in a dual-flow continuous fermenter (Hoover et al., 1976; Teather and Sauer, 1988), but to our knowledge no studies have been performed with the system described by Muetzel et al. (2009). Muetzel et al. (2009) modified the fermenters designed by Teather and Sauer (1988) with a different outflow that allowed the formation of a raft mat similar to that found in the rumen, which could help to maintain protozoa populations. Although total protozoa were maintained over the incubation period, holotrich protozoa decreased below the detection limit in all fermenters after 7-11 days, and numbers were lower than those found in vivo. Our hypothesis was that the fermenters of Muetzel et al. (2009) could be modified to improve the physical retention of protozoa. The objective of this work was to assess the effects of two modifications (sponge and a filter system) on protozoa numbers, concentrations of bacterial, protozoal, fungal and archaeal DNA, fermentation parameters and daily microbial biomass determined by using purine bases (PB) or bacterial or bacterial plus protozoal DNA. The modifications studied have been proven to be effective in other types of fermenters (Abe and Kurihara, 1984; Karnati et al., 2009), but have not been tested in those used in the present study.Other modifications of these fermenters, such as variations in the stirring frequency, dilution rate and the daily diet amount were recently investigated by Mason et al. (2015).

A second objective of this study was to compare values of microbial biomass determined using PB as a marker with concentrations of bacterial or bacterial plus protozoal DNA in the fermenters to assess if both procedures detected similar differences between experimental treatments. This comparison has been tested in vivo (Belanche et al., 2011) and in the semi-continuous Rusitec system

A

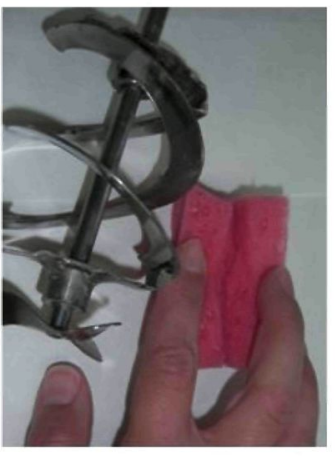

B

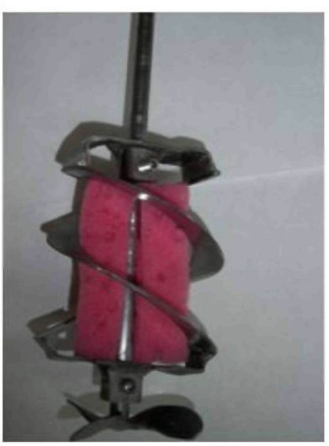

C

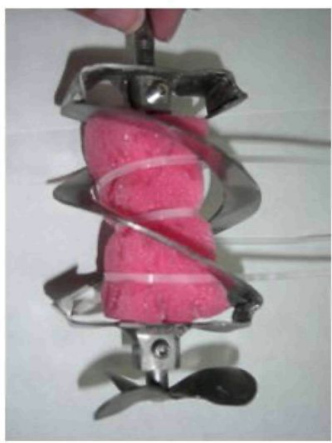

D

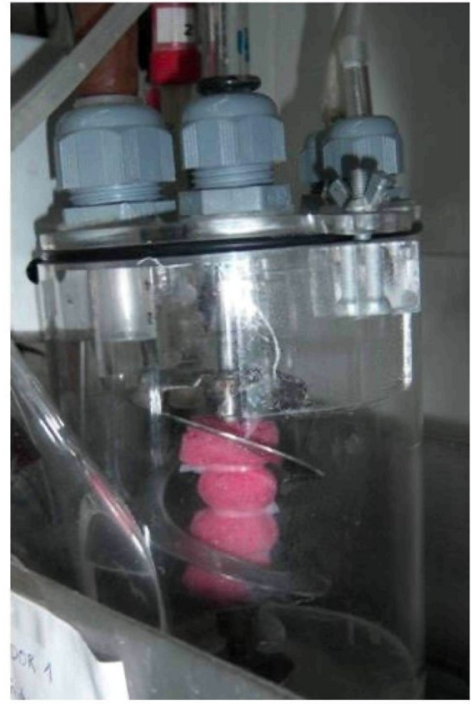

Fig. 1. Assembly of the sponge system (SP). A piece of a polyurethane sponge (A) was rolled around the axis of the stirring system (B) and fixed with plastic clamps (C) before placing the stirring system inside the fermenter (D). 
(Mateos et al., 2017) with contrasting results, but to our knowledge it has not been tested in continuous-culture fermenters.

\section{Materials and methods}

\subsection{Fermenters, treatments, animals and diets}

Six continuous culture fermenters with an effective volume of $1000 \mathrm{ml}$ were used in accordance with the system proposed by Teather and Sauer (1988) and as modified by Muetzel et al. (2009). These fermenters have a customized outlet projecting upwards at an angle of $45^{\circ} \mathrm{C}$ for the overflow, which according to Muetzel et al. (2009) allows a more constant dry matter (DM) concentration in the fermenter and helps to maintain protozoa populations. Two modifications of the fermenters were tested for its ability to promote rumen protozoa growth: inert polyurethane sponge cubes (SP) and a multistage filter system (FIL). The SP treatment consisted in a piece of a polyurethane sponge $(5 \times 6.5 \mathrm{~cm})$ which was rolled around the axis of the stirring system and fixed with plastic clamps (Fig. 1). The FIL treatment consisted of one layer of $50-\mu \mathrm{m}$ filter mounted on a perforated plastic cylinder $(1 \mathrm{~cm}$ diameter; $5 \mathrm{~cm}$ long; $0.5 \times 0.2 \mathrm{~cm}$ hole size), wrapped in a layer of foam to increase the protozoa retention, and then inserted into a wider perforated plastic cylinder ( $2 \mathrm{~cm}$ diameter; $5 \mathrm{~cm}$ long; $0.8 \times 0.4 \mathrm{~cm}$ hole size). The whole system was cut longitudinally and placed around the axis of the stirring system. A layer of polyester $100-\mu \mathrm{m}$ filter was used to cover the whole assembly in order to prevent clogging by feed particles before fixing it to the basis of the axis of the stirring system with plastic clamps (Fig. 2).

Four Segureña ewes $(55.1 \pm 7.62 \mathrm{~kg}$ body weight) fitted with permanent rumen cannula were used as donors of rumen contents for the experiment. Animals were fed at energy maintenance level (Aguilera et al., 1991) a diet composed of alfalfa hay and concentrate in a 50:50 ratio. Chemical composition of feed ingredients is given in Table 1 . Animals were fed once a day ( $9: 00 \mathrm{~h}$ ) for 15 days before starting the in vitro trials, and had free access to water and a mineral salt block (Pacsa Sanders, Seville, Spain). Animal procedures were performed in accordance with the Spanish guidelines for experimental animal protection (Royal Decree 53/2013 of February 1 st on the protection of animals used for experimentation or other scientific purposes) in line with European legislation (Directive 2010/63/UE).

A

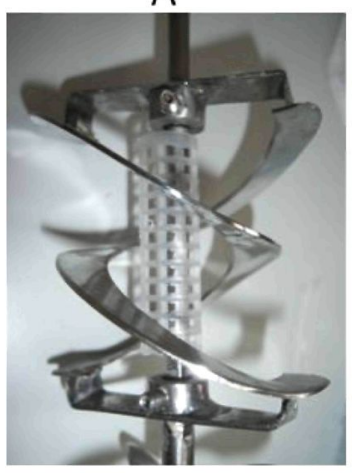

C



B

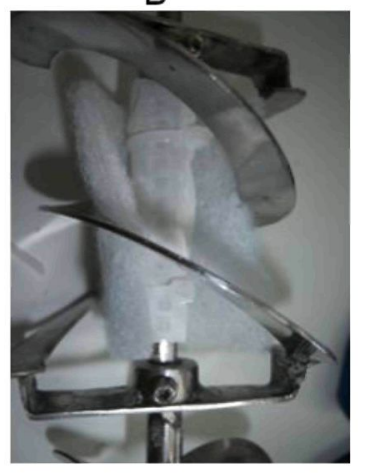

D

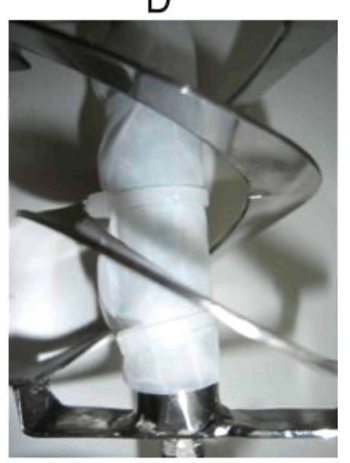

E

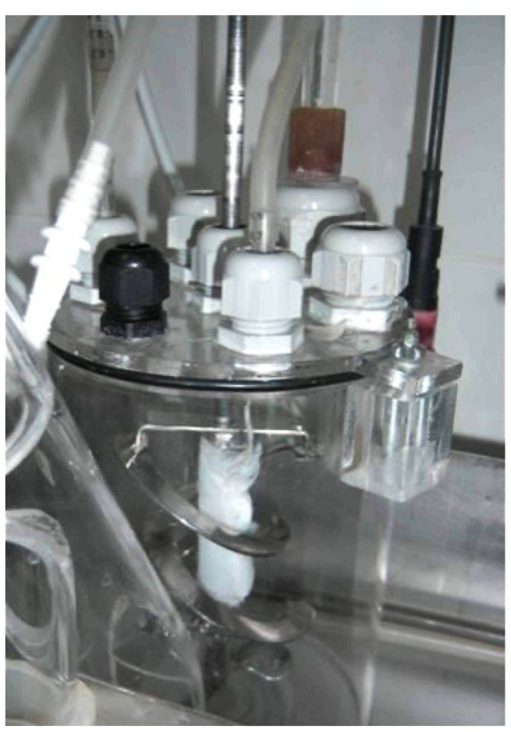

Fig. 2. Assembly of the filter system (FIL). One layer of 50- $\mu \mathrm{m}$ filter is mounted on a perforated plastic cylinder (A), wrapped in a layer of foam (B), and then inserted into a wider perforated plastic cylinder (C). The whole system was cut longitudinally, placed around the axis of the stirring system and covered with a layer of polyester $100-\mu \mathrm{m}$ filter before fixing it to the basis of the axis of the stirring system with plastic clamps (D). Finally the stirring system is placed inside the fermenter (E). 
Table 1

Chemical composition ( $\mathrm{g} / \mathrm{kg}$ dry matter unless other specified) of feed ingredients of the diet supplied to the animals and to continuous-culture fermenters. ${ }^{a}$

\begin{tabular}{lll}
\hline & Alfalfa hay & Concentrate \\
\hline Dry matter, g/kg fresh matter & 909 & 902 \\
Organic matter & 930 & 912 \\
Crude protein & 117 & 180 \\
Ether extract & 10.8 & 37.4 \\
Neutral detergent fiber & 550 & 334 \\
Acid detergent fiber & 435 & 130 \\
Acid detergent lignin & 126 & 31.9 \\
\hline
\end{tabular}

a Diet contained alfalfa hay and concentrate in 1:1 proportion. Fermenters received daily $30 \mathrm{~g}$ of diet (fresh matter basis).

\subsection{Experimental procedure and sampling}

Two identical 14-day incubation runs were carried out, and in each run two fermenters were randomly assigned to each of the experimental treatments: control (CON), SP and FIL, with the restriction that each fermenter should not receive the same treatment in the two periods. Rumen contents were collected from each animal immediately before the morning feeding, pooled, immediately transported to the laboratory in thermal bottles, and strained through 2 layers of cheesecloth. Each fermenter was inoculated with $700 \mathrm{ml}$ of rumen liquor within $30 \mathrm{~min}$ after rumen contents collection. Samples of rumen liquor were taken for protozoa counting as described below and about $30 \mathrm{ml}$ liquor were taken in sterile containers and kept at $-80^{\circ} \mathrm{C}$ for microbial DNA analyses. Each fermenter received $30 \mathrm{~g}$ (fresh matter basis; ground to $1 \mathrm{~mm}$ ) of the same diet than the one delivered to the fistulated animals supplied twice a day at 09:00 and 14:00. The flow through the fermenters was maintained by the continuous infusion of artificial saliva (McDougall, 1948) at a rate of $40 \mathrm{ml} / \mathrm{h}\left(4.0 \%\right.$ dilution rate), and $\mathrm{CO}_{2}$ was continuously infused into the fermenters to maintain anaerobic conditions. The effluent from each fermenter was collected into a vessel maintained at $3^{\circ} \mathrm{C}$ to prevent microbial growth.

The $\mathrm{pH}$ in the fermenter vessel was measured immediately before feeding every day. On incubation days $2,5,6,10$ and 14 , the total effluent from each fermenter was collected, homogenized and the weight and volume were recorded. Then, $5 \mathrm{ml}$ of effluent were added to $5 \mathrm{ml}$ of deproteinising solution ( $20 \mathrm{~g}$ metaphosphoric acid and $4 \mathrm{~g}$ crotonic acid per liter of $0.5 \mathrm{M} \mathrm{HCl}$ ) for volatile fatty acid (VFA) analysis; $2 \mathrm{ml}$ were added to $2 \mathrm{ml}$ of $0.5 \mathrm{M} \mathrm{HCl}$ for $\mathrm{NH}_{3}-\mathrm{N}$ analysis, and $5 \mathrm{ml}$ were immediately frozen for lactate analysis. All samples were kept at $-20^{\circ} \mathrm{C}$ until analyses. In addition, on days $2,6,10$ and 14 of incubation the following samples were taken from fermenters content by using a syringe without opening the fermenter: $5 \mathrm{ml}$ for protozoa counting, $3 \mathrm{ml}$ for determining enzymatic activity, and $20 \mathrm{~g}$ were stored in sterile containers for DNA extraction. Samples for protozoa counting were fixed in $5 \mathrm{ml}$ methyl green-formalin solution (Ogimoto and Imai, 1981) and stored at room temperature in the dark until protozoa counting. Samples for DNA extraction and enzymatic activity analysis were immediately frozen at $-80^{\circ} \mathrm{C}$.

The last day of each incubation period (day 14), the content of each fermenter was collected, weighed and homogenized before taken the following samples: about $500 \mathrm{ml}$ were subjected to a treatment with a saline solution containing methylcellulose (0.1\%) and used for bacteria isolation by differential centrifugation as described by Ramos et al. (2009). Pellets were then lyophilized, ground to a fine powder with a mortar and pestle, and analyzed for $\mathrm{N}$ and purine bases (PB) to estimate microbial $\mathrm{N}$ flow; about $100 \mathrm{~g}$ of fermenters content were frozen and freeze-dried before analysis of dry matter (DM), N and PB content.

\subsection{Extraction of DNA and $q P C R$ analysis}

The DNA was isolated in triplicate aliquots from freeze-dried fermenter contents $(50 \mathrm{mg})$ and extracted according to the procedure described by Yu and Morrison (2004), with the exception that an additional step for the treatment of samples with cetyltrimethylammonium bromide was included to remove PCR inhibitors (Saro et al., 2012). This procedure involves repeated beadbeating and the use of QIAamp DNA Stool Mini Kit columns (QIAgen, Valencia, CA, USA) to purify the DNA. The DNA absorbance ratios (A260:A280) were measured in a Nanodrop ND-1000 (Nano-Drop Technologies, Wilmington, DE) to test DNA quality.

Absolute quantification of total bacteria and protozoa in fermenters content samples was performed by qPCR using as standard DNA extracted from bacterial and protozoal pellets, respectively, and previously isolated from the rumen of sheep (Saro et al., 2012). The populations of fungi and methanogenic archaea were determined by qPCR in relation to the total bacterial population. Primers used for total bacteria and fungi have been described by Denman and McSweeney (2006), and those for protozoa and methanogenic archaea have been described by Sylvester et al. (2004) and Denman et al. (2007), respectively. The qPCR was performed in triplicate in an ABI PRISM 7000 Sequence Detection System (Applied Biosystems, Warrington, UK) as described by Saro et al. (2014) and with a PCR reaction mixture ( $20 \mu \mathrm{l}$ final volume) containing $10 \mu \mathrm{l} \mathrm{SYBR}$ Green PCR Master Mix (Applied Biosystems, Warrington, UK), $0.9 \mu \mathrm{l}$ of $20 \mu \mathrm{M}$ each primer, $6.2 \mu \mathrm{l}$ of milli Q water and $2 \mu \mathrm{l}$ of extracted DNA. Fungi and methanogenic archaea DNA concentrations were


threshold cycle after correcting for differences in amplification efficiencies between the target and the reference (total bacteria). 


\subsection{Chemical analyses}

Dry matter (ID 934.01), ash (ID 942.05), ether extract (EE; method ID 7.045) and crude protein (CP, method ID 984.13) were determined according to the Association of Official Analytical Chemists (2005). Analyses of aNDFom and ADFom (ID 973.18) were carried out according to Van Soest et al. (1991) using an ANKOM220 Fibre Analyzer unit (ANKOM Technology Corporation, Fairport, NY, USA) and sodium sulphite and heat-stable amylase. Both aNDFom and ADFom were expressed exclusive of residual ash. Total and individual VFA were analysed by gas chromatography using centrifuged samples of effluents, previously deproteinized with metaphosphoric acid, following the method described by Isac et al. (1994). The $\mathrm{NH}_{3}-\mathrm{N}$ and lactate concentrations were determined by colorimetric methods as described by García-Martínez et al. (2005). Xylanase and amylase activities were analyzed following the procedures described by Giraldo et al. (2007) at $\mathrm{pH} 6.5$ and $39^{\circ} \mathrm{C}$ in order to resemble optimal ruminal conditions and using oat spelt xylan and soluble starch as substrates, respectively. Concentrations of PB were determined according to Balcells et al. (1992).

Protozoa in preserved fluid samples were counted using a Neubauer Improved Bright-Line counting cell (Hauisser scientific, Horsham, PA). Holotrich protozoa were identified and their numbers were separately recorded. Duplicate preparations of each sample were counted and if either value differed from the average by more than $10 \%$, the counts were repeated.

\subsection{Calculations and statistical analyses}

Daily microbial $\mathrm{N}$ flow in fermenters was estimated by multiplying total non-ammonia $\mathrm{N}$ production in the effluents by the ratio PB: $\mathrm{N}$ in effluents/PB: $\mathrm{N}$ in bacterial pellets. The efficiency of microbial $\mathrm{N}$ synthesis was calculated by dividing the daily microbial $\mathrm{N}$ flow by the amount of degraded carbohydrates. The apparent degradability of total carbohydrates in the fermenters was calculated from the input of carbohydrates, estimated as the input of total organic matter - (CP + EE), and the output of carbohydrates corrected for the amount of hexoses in the VFA produced (Demeyer and van Nevel, 1979).

Time dependent data were analyzed as a mixed model with repeated measures using the PROC MIXED of SAS (SAS Inst. Inc., Cary, NC, USA). The statistical model used included treatment, period, time and treatment $\times$ time as fixed effects, and fermenter as a random effect. Data for each variable were analyzed using compound symmetry, unstructured, and autoregressive covariance structures, and the one that produced the minimum Akaike's information criterion was chosen. The effects were declared significant at $P<0.05$, and $P$ values $<0.10$ were considered a trend. When a significant effect of either treatment or time was detected, comparison of means was made by using the LSD test. Correlations between protozoal numbers and protozoal DNA concentrations were assessed on 48 pair values ( 4 fermenters $\times 3$ treatments $\times 4$ sampling times) by Pearson correlation analysis using the PROC CORR of SAS.

Data on microbial biomass were analyzed independently for each method (PB and DNA concentrations) as a mixed model which included treatment, period and treatment $x$ period as fixed effects, and fermenter as a random effect. Correlations between values of microbial biomass determined with PB as a marker or by quantifying bacterial and protozoal DNA were assessed by Pearson's correlation analysis using the PROC CORR of SAS. Finally, the associations among fermentation variables and microbial populations in the fermenters assessed on days 10 and 14 were investigated by principal component analysis (PCA) using the Statgraphics Centurion XVI statistical software version 16.2.04 (StatPoint Technologies, Inc., Herndon, VA, USA).

Table 2

Protozoal numbers assessed by microscopic counting and protozoal DNA concentrations in continuous-culture fermenters provided with modifications. ${ }^{1}$

\begin{tabular}{|c|c|c|c|c|c|c|c|c|c|c|c|c|}
\hline \multirow[b]{2}{*}{ Day } & \multicolumn{3}{|c|}{ Total protozoa $\left(\times 10^{3} / \mathrm{ml}\right)$} & \multicolumn{3}{|c|}{$\begin{array}{l}\text { Entodiniomorphid protozoa } \\
\left(\times 10^{3} / \mathrm{ml}\right)\end{array}$} & \multicolumn{3}{|c|}{ Holotrich protozoa $\left(\times 10^{3} / \mathrm{ml}\right)$} & \multicolumn{3}{|c|}{$\begin{array}{l}\text { Protozoal DNA ( } \mu \mathrm{g} / \mathrm{g} \text { fresh } \\
\text { matter) }\end{array}$} \\
\hline & $\mathrm{CON}$ & $\mathrm{SP}$ & FIL & $\mathrm{CON}$ & $\mathrm{SP}$ & FIL & $\mathrm{CON}$ & SP & FIL & $\mathrm{CON}$ & SP & FIL \\
\hline 2 & $62.9^{\mathrm{b}}$ & $47.7^{\mathrm{b}}$ & $58.2^{\mathrm{b}}$ & $56.4^{\mathrm{b}}$ & $44.5^{\mathrm{b}}$ & $51.3^{\mathrm{b}}$ & $6.50^{\mathrm{c}}$ & $3.15^{\mathrm{b}}$ & $5.07^{\mathrm{b}}$ & $3.53^{\mathrm{b}}$ & $3.77^{\mathrm{b}}$ & $3.93^{\mathrm{b}}$ \\
\hline 6 & $22.2^{\mathrm{a}}$ & $19.2^{\mathrm{a}}$ & $20.4^{\mathrm{a}}$ & $18.9^{\mathrm{ab}}$ & $17.1^{\mathrm{a}}$ & $18.4^{\mathrm{a}}$ & $3.30^{\mathrm{b}}$ & $2.10^{\mathrm{ab}}$ & $2.00^{\mathrm{a}}$ & $1.63^{\mathrm{a}}$ & $2.04^{\mathrm{a}}$ & $1.92^{\mathrm{a}}$ \\
\hline 10 & $13.2^{\mathrm{a}}$ & $22.2^{\mathrm{a}}$ & $17.3^{\mathrm{a}}$ & $11.6^{\mathrm{a}}$ & $19.9^{\mathrm{a}}$ & $15.6^{\mathrm{a}}$ & $1.72^{\mathrm{ab}}$ & $2.33^{\mathrm{ab}}$ & $1.65^{a}$ & $0.59^{a}$ & $1.12^{\mathrm{a}}$ & $1.15^{\mathrm{a}}$ \\
\hline 14 & $9.31^{\mathrm{a}}$ & $15.5^{\mathrm{a}}$ & $19.5^{\mathrm{a}}$ & $8.47^{\mathrm{a}}$ & $14.8^{\mathrm{a}}$ & $18.0^{\mathrm{a}}$ & $0.85^{a}$ & $0.70^{\mathrm{a}}$ & $1.50^{\mathrm{a}}$ & $0.56^{\mathrm{a}}$ & $0.90^{\mathrm{a}}$ & $0.80^{2}$ \\
\hline SEM & \multirow{2}{*}{\multicolumn{3}{|c|}{7.75}} & \multirow{2}{*}{\multicolumn{3}{|c|}{7.21}} & \multirow{2}{*}{\multicolumn{3}{|c|}{0.800}} & \multirow{2}{*}{\multicolumn{3}{|c|}{0.524}} \\
\hline$P$-value & & & & & & & & & & & & \\
\hline Treatment & \multicolumn{3}{|l|}{0.855} & \multicolumn{3}{|l|}{0.847} & \multicolumn{3}{|l|}{0.213} & \multicolumn{3}{|l|}{0.536} \\
\hline Time & \multicolumn{3}{|l|}{$\begin{array}{l}<0.001 \\
0.754\end{array}$} & \multicolumn{3}{|l|}{$\begin{array}{l}<0.001 \\
0.832\end{array}$} & \multicolumn{3}{|l|}{$\begin{array}{l}<0.001 \\
0.259\end{array}$} & \multicolumn{3}{|l|}{$<0.001$} \\
\hline $\begin{array}{c}\text { Treatment } x \\
\text { Time }\end{array}$ & \multicolumn{3}{|l|}{0.754} & \multicolumn{3}{|l|}{0.832} & \multicolumn{3}{|l|}{0.259} & \multicolumn{3}{|l|}{0.999} \\
\hline
\end{tabular}

\footnotetext{
a, b Mean values within a column with unlike superscripts differ $(\mathrm{P}<0.05)$.

Total, entodiniomorphid and holotrich protozoa numbers and protozoal DNA concentration in the inoculum were 938,843 and $95.0 \times 10^{3} / \mathrm{ml}$ and $26.8 \mu \mathrm{g} / \mathrm{g}$ fresh matter, respectively.

${ }^{1}$ CON: fermenters with no modification; SP and FIL: fermenters were provided with a sponge or a filter system, respectively.
} 


\section{Results}

Total, entodiniomorphid and holotrich protozoa numbers and protozoal DNA concentration in the inoculum were 938,843 and $95.0 \times 10^{3} / \mathrm{ml}$ and $26.8 \mu \mathrm{g} / \mathrm{g}$ fresh matter, respectively. The modifications tested in this study did not affect either total protozoa $(P=0.855)$, entodiniomorphid $(P=0.847)$ and holotrich $(P=0.213)$ protozoa numbers or the abundance of protozoal DNA $(P=0.536)$ in the fermenters over the incubation period (Table 2). Both total protozoa numbers and protozoal DNA concentrations decreased with time $(P<0.001)$ for all experimental treatments, but there were no differences $(P>0.05)$ among the values determined on sampling days 6, 10 and 14. Results from protozoal DNA concentration determined in each fermenter on the different sampling days were positively correlated $(P<0.001 ; \mathrm{n}=48)$ with the numbers of total $(\mathrm{r}=0.826)$, entodiniomorphid $(\mathrm{r}=0.824)$ and holotrich $(r=0.675)$ protozoa determined by microscopic counting.

Similarly to that observed for protozoa numbers, total bacterial DNA concentration and the relative abundance of fungal DNA in fermenters content determined on days 10 and 14 were not affected by any modification $(P=0.938$ and 0.806 , respectively; Table 3). In contrast, the relative abundance of methanogenic archaeal DNA tended $(P=0.060)$ to be affected by the experimental treatments, and it was greater $(P=0.049)$ in FIL than in SP fermenters. Bacterial DNA increased $(P<0.001)$, whereas the relative abundance of fungi and methanogenic archaea decreased $(P<0.001)$ from day 10 to day 14 of incubation. There were no treatment $\mathrm{x}$ sampling day interactions ( $P=0.109$ to 0.999 ) for any microbial population analyzed.

As shown in Table 4 , the modifications of fermenters had no effect $(P=0.412$ to 0.946$)$ on either total VFA production or molar proportions of individual VFA, but some of these parameters were affected by sampling time. Total VFA production and propionate proportions increased $(P<0.001)$ and acetate proportions decreased $(P<0.001)$ with incubation time, but values remained unchanged from day 10 to day $14(P>0.05)$. Molar proportions of butyrate and minor VFA (calculated as the sum of isobutyrate, isovalerate and valerate) remained unchanged over the whole incubation period ( $P=0.223$ and 0.127 , respectively). In agreement with that observed for VFA production, the $\mathrm{pH}$ values, concentrations of $\mathrm{NH}_{3}-\mathrm{N}$ and lactate, and amylase and xylanase activities were not affected ( $P=0.481$ to 0.961 ) by the modifications made in the fermenters (Table 5). However, $\mathrm{pH}^{\mathrm{values}}$ and $\mathrm{NH}_{3}-\mathrm{N}$ concentrations were affected by sampling day $(P<0.001)$. The $\mathrm{pH}$ values decreased from day 2 to day 6 , and then remained stable. The $\mathrm{NH}_{3}-\mathrm{N}$ concentration decreased from day 2 to day 10 , but there were no differences $(P>0.05)$ between the values determined on days 10 and 14 .

Microbial biomass, quantified either by using PB as a microbial marker or bacterial DNA and bacterial plus protozoal DNA was not affected ( $P=0.908-0.914$ ) by the fermenters modifications (Table 6 ). Similarly, the efficiency of microbial biomass produced was not affected by any treatment $(P=0.624)$. There were significant relationships between the values of microbial biomass obtained with PB and both the amount of bacterial DNA $(\mathrm{r}=0.657 ; P=0.020 ; \mathrm{n}=12)$ and that of bacterial plus protozoal DNA ( $\mathrm{r}=0.794$; $P=0.002 ; \mathrm{n}=12$ ) in each fermenter.

The PCA in Fig. 3 shows how samples from different fermenters grouped according to fermentation parameters and microbial populations abundance determined on days 10 and 14 of incubation. The direction of each vector indicates an increasing value of the corresponding variable, the angle between the vectors indicates the degree to which they are correlated and their length shows the importance of that variable to classify the samples. The PCA segregated samples by component 2 into two groups corresponding to sampling days regardless of the experimental treatment. Nine out of the 12 samples taken on day 14 grouped below axis 2 , whereas all samples from day 10, excepting one from CON treatment, were above. Within each group, there was no clear grouping according to the experimental treatment. Percentages of variance explained by the principal coordinates 1 and 2 were 28.26 and $18.93 \%$, respectively. Samples from day 14, especially those from FIL fermenters, were related with greater acetate proportions and acetate/ propionate ratios and amylase activity and bacterial DNA concentration, whereas samples from day 10 were related to greater fungi and archaea abundances.

Table 3

Concentrations of total bacterial DNA and relative abundance of fungal and methanogenic archaeal DNA in the contents of continuous-culture fermenters provided with modifications after 10 and 14 days of incubation. ${ }^{1}$

\begin{tabular}{|c|c|c|c|c|c|c|c|c|c|}
\hline \multirow[b]{3}{*}{ Day } & & & & \multicolumn{6}{|c|}{ Relative abundance of ${ }^{2}$} \\
\hline & \multicolumn{3}{|c|}{ Bacterial DNA $/ \mathrm{g}$ fresh matter } & \multicolumn{3}{|c|}{ Fungal DNA } & \multicolumn{3}{|c|}{ Methanogenic archaeal DNA } \\
\hline & $\mathrm{CON}$ & SP & FIL & $\mathrm{CON}$ & SP & FIL & $\mathrm{CON}$ & $\mathrm{SP}$ & FIL \\
\hline 10 & 20.6 & 19.5 & 20.7 & 0.20 & 0.14 & 0.17 & 1.47 & 1.12 & 1.54 \\
\hline 14 & 37.6 & 38.9 & 38.1 & 0.07 & 0.10 & 0.10 & 0.85 & 0.96 & 1.01 \\
\hline SEM & 3.87 & & & 0.024 & & & 0.104 & & \\
\hline \multicolumn{10}{|l|}{$P$-value } \\
\hline Treatment & 0.938 & & & 0.806 & & & 0.060 & & \\
\hline Time & $<0.001$ & & & 0.002 & & & $<0.001$ & & \\
\hline Treatment $\mathrm{x}$ Time & 0.951 & & & 0.279 & & & 0.109 & & \\
\hline
\end{tabular}

Total bacterial DNA concentration in the inoculum was $152.0 \mu \mathrm{g}$ bacterial DNA/g fresh matter. Values of relative abundance of fungi and methanogenic archaeal DNA were 4.26 and 0.175 , respectively.

${ }^{1}$ CON: fermenters with no modification; SP and FIL: fermenters were provided with a sponge or a filter system, respectively.

${ }^{2}$ Fungal and archaeal DNA measured relative to total bacterial DNA. Values expressed as $10^{3} \times 2^{-\Delta C t}$. 
Table 4

Total volatile fatty acid (VFA) production and molar proportion of individual VFA in continuous-culture fermenters provided with modifications. ${ }^{1}$

\begin{tabular}{|c|c|c|c|c|c|c|c|c|c|c|c|c|c|c|c|}
\hline \multirow[b]{3}{*}{ Day } & & & & \multicolumn{12}{|c|}{ Molar proportions $(\mathrm{mol} / 100 \mathrm{~mol})$} \\
\hline & \multicolumn{3}{|c|}{ Total VFA (mmol/d) } & \multicolumn{3}{|l|}{ Acetate } & \multicolumn{3}{|c|}{ Propionate } & \multicolumn{3}{|c|}{ Butyrate } & \multicolumn{3}{|c|}{ Minor VFA ${ }^{2}$} \\
\hline & CON & $\mathrm{SP}$ & FIL & $\mathrm{CON}$ & $\mathrm{SP}$ & FIL & $\mathrm{CON}$ & $\mathrm{SP}$ & FIL & CON & $\mathrm{SP}$ & FIL & $\mathrm{CON}$ & $\mathrm{SP}$ & FIL \\
\hline 2 & $44.9^{\mathrm{a}}$ & $42.9^{2}$ & $45.1^{\mathrm{a}}$ & $59.4^{\mathrm{b}}$ & $58.8^{\mathrm{b}}$ & $59.3^{\mathrm{b}}$ & $20.3^{\mathrm{a}}$ & $21.2^{\mathrm{a}}$ & $3.69^{\mathrm{b}}$ & 14.0 & 13.8 & 14.1 & 6.36 & 6.20 & 7.15 \\
\hline 6 & $50.0^{\mathrm{ab}}$ & $49.6^{\mathrm{ab}}$ & $48.7^{\mathrm{a}}$ & $54.9^{\mathrm{a}}$ & $55.6^{\mathrm{a}}$ & $56.0^{\mathrm{a}}$ & $23.2^{\mathrm{b}}$ & $22.9^{\mathrm{b}}$ & $3.25^{\mathrm{ab}}$ & 15.0 & 14.5 & 14.3 & 6.90 & 6.97 & 6.90 \\
\hline 10 & $55.0^{\mathrm{b}}$ & $55.5^{\mathrm{ab}}$ & $54.3^{\mathrm{bc}}$ & $54.8^{\mathrm{a}}$ & $55.3^{\mathrm{a}}$ & $55.1^{\mathrm{a}}$ & $23.8^{\mathrm{b}}$ & $23.5^{\mathrm{b}}$ & $3.19^{\mathrm{a}}$ & 14.7 & 14.1 & 14.9 & 6.89 & 7.09 & 6.76 \\
\hline 14 & $53.6^{\mathrm{ab}}$ & $55.1^{\mathrm{ab}}$ & $57.4^{\mathrm{c}}$ & $55.0^{\mathrm{a}}$ & $56.5^{\mathrm{a}}$ & $55.9^{\mathrm{a}}$ & $23.6^{\mathrm{b}}$ & $23.6^{\mathrm{b}}$ & $3.03^{\mathrm{a}}$ & 14.6 & 13.8 & 14.0 & 6.82 & 6.50 & 6.75 \\
\hline SEM & 2.64 & & & 0.73 & & & 0.52 & & & 0.437 & & & & 0.21 & \\
\hline \multicolumn{16}{|l|}{$P$-value } \\
\hline Treatment & 0.946 & & & 0.889 & & & 0.412 & & & 0.882 & & & & 0.483 & \\
\hline Time & $<0.001$ & & & $<0.00$ & & & $<0.00$ & & & 0.223 & & & & 0.127 & \\
\hline Treatment $\times$ Time & 0.948 & & & 0.876 & & & 0.684 & & & 0.905 & & & & 0.087 & \\
\hline
\end{tabular}

a, b Mean values within a column with unlike superscripts differ $(\mathrm{P}<0.05)$.

${ }^{1}$ CON: fermenters with no modification; SP and FIL: fermenters were provided with a sponge or a filter system, respectively.

${ }^{2}$ Calculated as the sum of isobutyrate, isovalerate and valerate.

Table 5

Values of $\mathrm{pH}, \mathrm{NH}_{3}-\mathrm{N}$ and lactate concentrations, and enzymatic activities in continuous-culture fermenters provided with modifications. ${ }^{1}$

\begin{tabular}{|c|c|c|c|c|c|c|c|c|c|c|c|c|c|c|c|}
\hline \multirow[b]{2}{*}{ Day } & \multicolumn{3}{|l|}{$\mathrm{pH}$} & \multicolumn{3}{|c|}{$\mathrm{NH}_{3}-\mathrm{N}(\mathrm{mg} / 100 \mathrm{ml})$} & \multicolumn{3}{|c|}{ Lactate $(\mathrm{mg} / \mathrm{l})$} & \multicolumn{3}{|c|}{ Amylase $^{2}$} & \multicolumn{3}{|c|}{ Xylanase $^{2}$} \\
\hline & $\mathrm{CON}$ & SP & FIL & $\mathrm{CON}$ & SP & FIL & $\mathrm{CON}$ & SP & FIL & $\mathrm{CON}$ & SP & FIL & $\mathrm{CON}$ & SP & FIL \\
\hline 2 & $6.49^{\mathrm{b}}$ & $6.54^{\mathrm{b}}$ & $6.51^{\mathrm{b}}$ & $42.0^{c}$ & $42.4^{\mathrm{b}}$ & $40.1^{c}$ & 9.82 & 9.68 & 8.21 & 0.058 & 0.063 & 0.056 & 0.552 & 0.477 & 0.520 \\
\hline 6 & $6.24^{\mathrm{a}}$ & $6.28^{\mathrm{a}}$ & $6.23^{\mathrm{a}}$ & $34.3^{\mathrm{b}}$ & $31.2^{\mathrm{a}}$ & $37.7^{\mathrm{b}}$ & 8.60 & 9.24 & 8.96 & 0.064 & 0.047 & 0.040 & 0.415 & 0.402 & 0.395 \\
\hline 10 & $6.23^{\mathrm{a}}$ & $6.25^{\mathrm{a}}$ & $6.25^{\mathrm{a}}$ & $31.3^{\mathrm{ab}}$ & $29.2^{\mathrm{a}}$ & $29.9^{\mathrm{a}}$ & 10.2 & 8.72 & 9.98 & 0.040 & 0.044 & 0.037 & 0.453 & 0.453 & 0.468 \\
\hline 14 & $6.21^{\mathrm{a}}$ & $6.23^{\mathrm{a}}$ & $6.23^{\mathrm{a}}$ & $29.0^{\mathrm{a}}$ & $28.9^{\mathrm{a}}$ & $28.7^{\mathrm{a}}$ & 9.78 & 10.5 & 10.4 & 0.081 & 0.092 & 0.082 & 0.435 & 0.428 & 0.490 \\
\hline SEM & 0.035 & & & 1.36 & & & 1.01 & & & 0.0213 & & & & 0.0563 & \\
\hline \multicolumn{16}{|l|}{$P$-value } \\
\hline Treatment & 0.481 & & & 0.681 & & & 0.961 & & & 0.849 & & & & 0.751 & \\
\hline Time & $<0.001$ & & & $<0.001$ & & & 0.432 & & & 0.085 & & & & 0.138 & \\
\hline Treatment $\times$ Time & 0.993 & & & 0.768 & & & 0.778 & & & 0.996 & & & & 0.977 & \\
\hline
\end{tabular}

a, b Mean values within a column with unlike superscripts differ $(\mathrm{P}<0.05)$.

${ }^{1}$ CON: fermenters with no modification; SP and FIL: fermenters were provided with a sponge or a filter system, respectively.

${ }^{2}$ Amylase activity is expressed as $\mu \mathrm{mol}$ of glucose released from soluble starch by $1 \mathrm{ml}$ of liquid fermenters' content in $1 \mathrm{~min}$ at $39^{\circ} \mathrm{C}$ and $\mathrm{pH} 6.5$. Xylanase activity is expressed as $\mu \mathrm{mol}$ of xylose liberated from oat spelt xylan by $1 \mathrm{ml}$ of liquid fermenters' content in $1 \mathrm{~min}$ at $39^{\circ} \mathrm{C}$ and $\mathrm{pH} 6.5$.

Table 6

Daily microbial biomass in continuous-culture fermenters provided with modifications determined by using purine bases (PB) as a microbial marker or from bacterial or bacterial plus protozoal DNA concentrations, and efficiency of microbial growth. ${ }^{a}$

\begin{tabular}{|c|c|c|c|c|c|}
\hline & $\mathrm{CON}$ & SP & FIL & SEM & $P$ value SEM \\
\hline PB (mg microbial N/d) & 203 & 215 & 205 & 20.3 & 0.914 \\
\hline Bacterial DNA (mg DNA/d) & 36.6 & 34.7 & 37.6 & 4.64 & 0.908 \\
\hline Bacterial plus protozoal DNA (mg DNA/d) & 37.2 & 35.5 & 38.4 & 4.69 & 0.914 \\
\hline Efficiency of microbial growth, $g$ of microbial $N / \mathbf{k g}$ of digested carbohydrates ${ }^{b}$ & 12.2 & 13.2 & 13.5 & 0.938 & 0.624 \\
\hline
\end{tabular}

a CON: fermenters with no modification; SP and FIL: fermenters were provided with a sponge or a filter system, respectively.

b Calculated from microbial growth determined using $\mathrm{PB}$ as a microbial marker.

\section{Discussion}

The two modifications used in fermenters in this study were selected because they have been effective in increasing protozoa numbers in other types of fermenters (Abe and Kurihara, 1984; Karnati et al., 2009). Different types of fermenters have functional differences, such as dilution rate, solids retention time, amount of feed provided daily, frequency of feeding, etc. that affect fermentation characteristics and microbial populations (Carro et al., 2009). Therefore, previous results cannot be directly extrapolated to the fermenters used in the present study. The SP treatment was chosen because Abe and Kurihara (1984) observed that the introduction of synthetic sponge cubes to semi-continuous fermenters produced an enlargement of the area for protozoal sequestration and a suitable micro-habitat for the maintenance of Entodinium, large protozoa and holotrich protozoa. The design of the FIL treatment followed that of Karnati et al. (2009), but its location inside the fermenter was different. Karnati et al (2009) placed the filter system on the filtrate pumps of dual-flow continuous-culture fermenters (Hoover et al., 1976), and therefore the FIL acted as a 


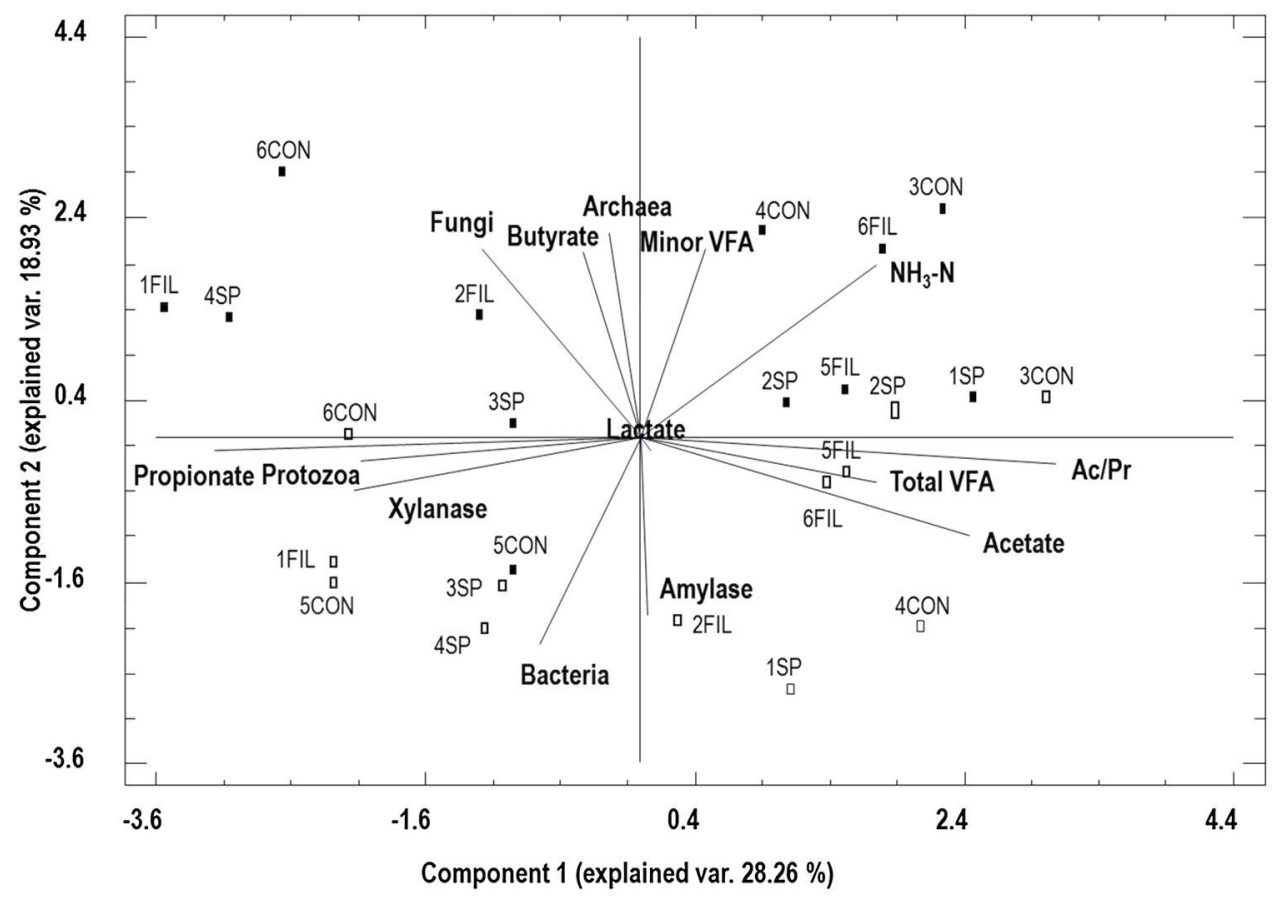

Fig. 3. Principal component analysis plot of microbial populations DNA concentration and fermentation parameters, with vectors indicating increasing values. Samples from fermenters (1-6) without modification (CON) and provided with a polyurethane sponge (SP) or a filter system (FIL). Points are marked according sampling time on day 10 (full squares) and 14 (empty squares) after inoculation.

barrier retaining protozoa inside the fermenters. Before conducting the trials reported here, we tried to place the FIL at the overflow port, but the filters were blocked and prevented the outflow of effluent. This was probably caused by the layout of the overflow port in these fermenters, as the effluent should be lifted upwards before flowing out. Therefore, FIL was mounted on the axis of the stirring system as before described (Fig. 2), and our hypothesis was that protozoa might enter the assembly by the opening at the top and be retained inside.

Contrary to our expectations, none of the modifications was successful in retaining high numbers of protozoa inside the fermenters. However, it should be noted that protozoa numbers after 14 days of incubation were 1.7 and 2.1 times greater in SP and FIL fermenters than in CON ones, respectively, although the differences did not reach the significance level due to the high individual variability among fermenters. Protozoa decreased markedly over the 6 first days of incubation and total protozoa numbers at day 6 were about 46 times in average lower than those in the inoculum (42.3, 48.9 and 46.0 times for CON, SP and FIL, respectively). These values are lower than the decreases reported by others ( $\geq 100$-fold) in different types of fermenters during the first days of incubation (Carro et al., 1995; Moumen et al., 2009; Karnati et al., 2009; Martínez et al., 2010), which was attributed to protozoa sequestration in the raft matt formed inside the fermenters (Muetzel et al., 2009). The qPCR analyses detected lower decreases of protozoa over the first 6 incubation days than the microscopic counting, with concentrations of protozoal DNA being 16.4, 13.1 and 14.0 times lower in CON, SP and FIL fermenters compared with the ruminal inoculum. The fact that lysed protozoa are not counted by microscopy, but free DNA is quantified in the qPCR analysis can help to explain the observed differences between both methods of quantifying protozoa.

Although the maintenance of holotrich protozoa in ruminal fermenters is especially difficult due to their long generation time, in our study holotrich protozoa were detected in all fermenters after 14 days of incubation. The proportion of holotrich in FIL-fermenters was relatively constant over the incubation period $(10.5,13.3,13.2$ and $11.1 \%$ of total protozoa at $2,6,10$ and 14 days of incubation, respectively), but decreased with time in both CON (from $10.9 \%$ at day 2-6.69\% at day 14) and SP (from 10.9 at day 2 to $6.89 \%$ at day 14) fermenters. These results indicate that FIL was effective in maintaining holotrich protozoa proportions similar to those found in the inoculum (10.1\%) and in the rumen of sheep fed similar diets (Saro et al., 2014). In contrast, holotrich protozoa have been reported to disappear by the end of the incubation period in many studies conducted with different types of fermenters (Carro et al., 1995; Moumen et al., 2009; Hristov et al., 2012). Muetzel et al. (2009) also observed that holotrich protozoa decreased below the detection limit after about 7-11 days in the same fermenters used in the present study which were fed a high-forage diet.

Total protozoa numbers in the CON fermenters were similar to those reported by Muetzel et al. (2009) after 16 days of incubation using the same type of fermenters, although in the same study protozoa populations almost disappeared when fermenters were inoculated with rumen fluid from a different cow. Mason et al. (2015) reported also similar protozoa numbers $\left(13 \times 10^{3} / \mathrm{ml}\right.$ after 10 days of incubation) in the same type of fermenters with intermittent stirring, but numbers dropped to about $0.8 \times 10^{3} / \mathrm{ml}$ with continuously stirring. In contrast, total protozoa numbers in SP and FIL fermenters in our study were greater than those reported in the previously cited studies. However, direct comparison of protozoa numbers in different studies is complicate, as they are affected 
by many factors, such as protozoa concentrations in the ruminal inoculum, feeding level, dilution rate, pH and stirring setting, among others (Carro et al., 1995; Martínez et. al., 2010; Mason et al., 2015).

Numbers of protozoa in fermenters have been classically determined by microscopic counting, but qPCR has been probed as a useful tool to quantify the amount of protozoal DNA in ruminal samples (Sylvester et al., 2004). However, only few studies have compared the results obtained with the two techniques. In the present study, both techniques detected significant decreases of protozoa numbers with time, and the values obtained with the two methods were significantly correlated. In agreement with our results, Skillman et al. (2006) observed a highly significant correlation between protozoa numbers in sheep determined by microscopic counting and protozoal DNA concentrations assessed by qPCR with primers specifically designed to target Entodinium and Dasytricha spp. In contrast, Tan et al. (2011) in an in vitro study and Saro et al. (2014) in ruminal samples from sheep observed no significant correlation between protozoa numbers determined by microscopic counting and protozoal DNA concentrations assessed by qPCR. Differences in the primers used in the different studies and the fact that lysed protozoa are not counted by microscopy may explain the lack of correlation between the results obtained by microscopic counting and qPCR in some studies (Saro et al., 2014).

The other studied microbial populations developed in the fermenters were not influenced by any of the modifications tested, but they changed over the sampling period (days 10-14). The increase in bacterial DNA concentrations from day 10 to 14 was similar in all fermenters (1.83, 1.99 and 1.84-fold in CON, SP and FIL fermenters, respectively). This is in agreement with the results of Muetzel et al. (2009), who observed a 1.4-fold increase in bacterial rRNA from the adaptation to the measurement period in the same type of fermenters than those used in our study. Others have also reported an increase in bacterial DNA concentrations over the incubation period in continuous (Soto et al., 2013) and semi-continuous fermenters (Mateos et al., 2017). The greater bacterial DNA concentrations observed on day 14 are in accordance with the greater amylase activity values, which were 2.1 times greater (value averaged across treatments) on day 14 than on day 10. Similarly, the angle between the vectors for bacteria and amylase activity in the PCA analysis (Fig. 3) indicates a positive correlation between those variables. These results would suggest an increase of amylolytic bacteria by the end of the incubation period, which is consistent with the adequate $\mathrm{pH}$ values $(6.21-6.23)$ for the growth of this type of bacteria observed in all fermenters (Therion et al., 1982).

The relative abundance of fungal and archaeal DNA decreased significantly from day 10 to day 14 of incubation in all fermenters. In contrast, Muetzel et al. (2009) reported a 2.2-fold increase in fungal rRNA, with no changes in the concentrations of archaeal rRNA, from the adaptation to the measurement period for the same type of fermenters. It should be taken into account that the absolute abundance of rRNA was measured in the study of Muetzel et al. (2009), whereas the relative abundance of fungal and archaeal DNA to total bacterial DNA was measured in our study. Because bacterial DNA concentrations were greater on day 14 compared with day 10 , the decrease observed in the relative abundance of fungal and archaeal DNA on day 14 might be the consequence of the increased bacterial DNA concentrations and may indicate unchanged absolute concentrations of fungi and archaea.

In accordance with the lack of effects of the fermenters modifications on microbial populations, no differences were observed either in fermentation parameters, but most fermentation parameters changed over the incubation period. The reductions in acetate and increases in propionate proportions observed over the first 6 days of incubation are in line with the results of previous studies. Hristov et al. (2012) performed a meta-analysis involving 180 studies to compare ruminal fermentation in experiments with continuous-culture fermenters and in vivo data, and reported lower acetate and greater propionate proportions in continuous-culture fermenters than in vivo. The shifts in the proportions of acetate and propionate are consistent to the decrease in pH observed during incubation, as cellulolytic activity is reduced below $\mathrm{pH} 6.3$ (Therion et al., 1982). In contrast, the proportions of butyrate and minor VFA, lactate concentrations and xylanase activity remained unchanged over the incubation period. Most fermentative parameters were unchanged from day 6 to the end of the incubation period, which would indicate that a 6 -day adaptation period was adequate to reach relatively steady-state conditions in this type of fermenters.

Belanche et al. (2011) compared estimates of microbial growth in lambs using PB as a microbial marker with those derived from bacterial and protozoal DNA sequences and concluded that microbial DNA sequences could be considered as potential internal markers to determine microbial synthesis in vivo. Our in vitro study confirmed their results, as none of the markers (PB and DNA) detected differences between the experimental treatments and the results from both methods were positively correlated. This would indicate the suitability of DNA sequences as microbial markers to estimate microbial biomass in vitro in continuous-culture fermenters as well.

\section{Conclusions}

The two tested modifications increased numerically the protozoa numbers in continuous-culture fermenters, and the FIL allowed maintaining a proportion of holotrich protozoa similar to that in the ruminal fluid used to inoculate the fermenters, but differences did not reach statistical significance. These results encourage further studies combining the FIL treatment with an appropriate choice of mechanical agitation, feeding frequency and dilution rate to maintain protozoa populations over long incubation periods. The tested modifications did not affect the fermentation parameters, which reached a steady-state after 6 days of incubation. However, microbial populations abundance did not reach a steady state over the period comprised between day 10 and 14 of incubation. Both microscopic counting of protozoa and protozoal DNA quantification by qPCR are valid methods for assessing protozoa population in continuous-culture fermenters. Determining the amount of bacterial and bacterial plus protozoal DNA can be an appropriate method to estimate microbial biomass in continuous-culture fermenters, as the values were significantly correlated with those obtained using purine bases as a microbial marker. 


\section{Conflicts of interest}

The authors of the manuscript entitled "Effects of modifications to retain protozoa in continuous-culture fermenters on ruminal fermentation, microbial populations, and microbial biomass assessed by two different methods" declare that there are no conflicts of interest.

\section{Acknowledgement}

Financial support was from the Spanish Ministry of Economy and Competitiveness under the Project AGL2011-22628.

\section{References}

Abe, M., Kurihara, Y., 1984. Long-term cultivation of certain rumen protozoa in a continuous fermentation system supplemented with sponge materials. J. Appl. Bacteriol. 56, 201-213. http://dx.doi.org/10.1111/j.1365-2672.1984.tb01340.x.

Aguilera, J.F., Lara, L., Molina, E., Prieto, C., 1991. Energy balance studies with growing granadina goats during fasting and maintenance. Small Rumin. Res. 5, 109-115. http://dx.doi.org/10.1017/0921-4488(91)90035.

Association of Official Analytical Chemists, 2005. Official Methods of Analysis, 18th ed. AOAC Chemists, Gaithersburg, MD, USA.

Balcells, J., Guada, J.A., Peiró, J.M., Parker, D.S., 1992. Simultaneous determination of allantoin and oxypurines in biological fluids by high-performance liquid chromatography. J. Chromatogr. B Biomed. Sci. Appl. 575, 153-157. http://dx.doi.org/10.1016/0378-4347(92)80517-T.

Belanche, A., Abecia, L., Holtrop, G., Guada, A.J., Castrillo, C., de la Fuente, G., Balcells, J., 2011. Study of the effect of the presence or absence of protozoa on rumen fermentation and microbial protein contribution to the chyme. J. Anim. Sci. 89, 4163-4174. http://dx.doi.org/10.2527/jas.2010-3703.

Broudiscou, L.P., Papon, Y., Fabre, M., Broudiscou, A.F., 1997. Maintenance of rumen protozoa populations in a dual outflow continuous fermenter. J. Sci. Food Agric. 75, 273-280. http://dx.doi.org/10.1002/(SICI)1097-0010.

Carro, M.D., Lebzien, P., Rohr, K., 1995. Effects of pore size of nylon bags and dilution rate on fermentation parameters in a semi-continuous artificial rumen. Small Rumin. Res. 15, 113-119. http://dx.doi.org/10.1016/0921-4488(94)00015-Y.

Carro, M.D., Ranilla, M.J., Martín-García, I., Molina-Alcaide, E., 2009. Comparison of microbial fermentation of high- and low-forage diets in sheep rumen and two types of fermenters. Animal 3-4, 527-534. http://dx.doi.org/10.1017/S1751731108003844.

Demeyer, D., Van Nevel, C., 1979. Effect of defaunation on the metabolism of rumen micro-organisms. Br. J. Nutr. 42, 515-524. http://dx.doi.org/10.1079/ BJN19790143.

Denman, S.E., McSweeney, C.S., 2006. Development of a real-time PCR assay for monitoring anaerobic fungal and cellulolytic bacterial populations within the rumen. FEMS Microbiol. Ecol. 58, 572-582. http://dx.doi.org/10.1111/j.1574-6941.2006.00190.x.

Denman, S.E., Tomkins, N.W., McSweeney, C.S., 2007. Quantitation and diversity analysis of ruminal methanogenic populations in response to the antimethanogenic compound bromochloromethane. FEMS Microbiol. Ecol. 62, 313-322. http://dx.doi.org/10.1111/j.1574-6941.2007.00394.

García-Martínez, R., Ranilla, M.J., Tejido, M.L., Carro, M.D., 2005. Effects of disodium fumarate on in vitro rumen microbial growth, methane production and fermentation of diets differing in their forage:concentrate ratio. Br. J. Nutr. 94, 71-77. http://dx.doi.org/10.1079/BJN20051455.

Giraldo, L.A., Tejido, M.L., Ranilla, M.J., Carro, M.D., 2007. Effects of exogenous cellulase supplementation on microbial growth and ruminal fermentation of a highforage diet in rusitec fermenters. J. Anim. Sci. 85, 1962-1970. http://dx. doi.org/10.2527/jas.2006-318.

Hillman, K., Williams, A.G., Lloyd, D., 1991. Evaluation of matrices in the rumen simulation technique (RUSTTEC) for the maintenance of ciliate protozoa. Lett. Appl. Microbiol. 12, 129-132. http://dx.doi.org/10.1111/j.1472-765X.1991.tb00522.x.

Hoover, W.H., Grooker, B.A., Sniffen, C.J., 1976. Effects of differential solid-liquid removal rates on protozoa numbers in continuous cultures of rumen contents. J. Anim. Sci. 43, 528-534. http://dx.doi.org/10.2527/jas1976.432528x.

Hristov, A.N., Lee, C., Hristova, R., Huhtanen, P., Firkins, J.L., 2012. A meta-analysis of variability in continuous-culture ruminal fermentation and digestibility data. J. Dairy Sci. 95, 5299-5307. http://dx.doi.org/10.3168/jds.2012-5533.

Isac, M.D., García, M.A., Aguilera, J.F., Molina-Alcaide, E., 1994. A comparative study of nutrient digestibility, kinetics of digestion and passage and rumen fermentation pattern in goats and sheep offered medium quality forages at the maintenance level of feeding. Arch. Tierernahr. 46, 37-50. http://dx.doi.org/10.1016/ S0301-6226(99)00149-9.

Karnati, S.K.R., Sylvester, J.T., Ribeiro, C.V.D.M., Gilligan, L.E., Firkins, J.L., 2009. Investigating unsaturated fat, monensin, or bromoethanesulfonate in continuous cultures retaining ruminal protozoa. I. Fermentation, biohydrogenation, and microbial protein synthesis. J. Dairy Sci. 92 , 3849-3860. http://dx.doi.org/10.3168/ jds.2008-1436.

Mansfield, H.R., Endres, M.I., Stern, M.D., 1995. Comparison of microbial fermentation in the rumen of dairy cows and dual flow continuous culture. Anim. Feed Sci. Technol. 55, 47-66. http://dx.doi.org/10.1016/0377-8401(95)98202-8.

Martínez, M.E., Ranilla, M.J., Tejido, M.L., Saro, C., Carro, M.D., 2010. Comparison of fermentation of diets of variable composition in the rumen of sheep and rusitec fermenters: II. Protozoa populations and diversity of bacterial communities. J. Dairy Sci. 93, 3699-3712. http://dx.doi.org/10.3168/jds.2009-2934.

Mason, F., Zanfi, C., Spanghero, M., 2015. Testing a stratified continuous rumen fermenter system. Anim. Feed Sci. Technol. 201, 104-109. http://dx.doi.org/10. 1016/j.anifeedsci.2015.01.008.

Mateos, I., Ranilla, M., Saro, C., Carro, M.D., 2015. Comparison of fermentation characteristics and bacterial diversity in the rumen of sheep and in batch cultures of rumen microorganisms. J. Agric. Sci. 153, 1097-1106. http://dx.doi.org/10.1017/S0021859615000167.

Mateos, I., Ranilla, M., Saro, C., Carro, M.D., 2017. Shifts in microbial populations in rusitec fermenters as affected by the type of diet and impact of the method for estimating microbial growth ( ${ }^{15} \mathrm{~N}$ vs. Microbial DNA). Animal 11, 1939-1948. http://dx.doi.org/10.1017/S1751731117000878.

McDougall, E.I., 1948. Studies on ruminant saliva. 1. The composition and output of sheep's saliva. Biochem. J. 43, 99-109.

Moumen, A., Yáñez-Ruiz, D.R., Carro, M.D., Molina-Alcaide, E., 2009. Protozoa evolution in single-flow continuous culture and Rusitec fermenters fed high-forage diets. Options Méditerranéenes 85, 303-308.

Muetzel, S., Lawrence, P., Hoffmann, E.M., Becker, K., 2009. Evaluation of a stratified continuous rumen incubation system. Anim. Feed Sci. Technol. 151, $32-43$. http://dx.doi.org/10.1016/j.anifeedsci.2008.11.001.

Ogimoto, K., Imai, S., 1981. Atlas of Rumen Microbiology. Scientific Societies Press, Tokyo, Japan.

Ramos, S., Tejido, M.L., Martínez, M.E., Ranilla, M.J., Carro, M.D., 2009. Microbial protein synthesis, ruminal digestion, microbial populations, and nitrogen balance in sheep fed diets varying in forage-to-concentrate ratio and type of forage1. J. Anim. Sci. 87, 2924-2934. http://dx.doi.org/10.2527/jas.2009-1938.

Saro, C., Ranilla, M.J., Carro, M.D., 2012. Postprandial changes of fiber-degrading microbes in the rumen of sheep fed diets varying in type of forage as monitored by real-time PCR and automated ribosomal intergenic spacer analysis. J. Anim. Sci. 90, 4487-4494. http://dx.doi.org/10.2527/jas.2012-5265.

Saro, C., Ranilla, M.J., Tejido, M.L., Carro, M.D., 2014. Influence of forage type in the diet of sheep on rumen microbiota and fermentation characteristics. Livest. Sci. 160, 52-59. http://dx.doi.org/10.1016/j.livsci.2013.12.005.

Skillman, L.C., Toovey, A.F., Williams, A.J., Wright, A.D., 2006. Development and validation of a real-time PCR method to quantify rumen protozoa and examination of variability between entodinium populations in sheep offered a hay-based diet. Appl. Environ. Microbiol. 72, 200-206. http://dx.doi.org/10.1128/AEM.72.1. 200-206.2006.

Soto, E.C., Molina-Alcaide, E., Khelil, H., Yañez-Ruiz, D.R., 2013. Ruminal microbiota developing in different in vitro simulation systems inoculated with goats' rumen liquor. Anim. Feed Sci. Technol. 185, 9-18. http://dx.doi.org/10.1016/j.anifeedsci.2013.06.003. 
Sylvester, J.T., Karnati, S.K.R., Yu, Z., Morrison, M., Firkins, J.L., 2004. Development of an assay to quantify rumen ciliate protozoal biomass in cows using real-time PCR. J. Nutr. 134, 3378-3384.

Tan, H.Y., Sieo, C.C., Abdullah, N., Liang, J.B., Huang, X.D., Ho, Y.W., 2011. Effects of condensed tannins from Leucaena on methane production, rumen fermentation and populations of methanogens and protozoa in vitro. Anim. Feed Sci. Technol. 169, 185-193. http://dx.doi.org/10.1016/j.anifeedsci.2011.07.004.

Teather, R.M., Sauer, F.D., 1988. A naturally compartmented rumen simulation system for the continuous culture of rumen bacteria and protozoa. J. Dairy Sci. 71 , 666-673. http://dx.doi.org/10.3168/jds.S0022-0302(88)79605-8.

Therion, J.J., Kistner, A., Kornelius, J.H., 1982. Effect of $\mathrm{pH}$ on growth rates of rumen amylolytic and lactilytic bacteria. Appl. Environ. Microbiol. 44, $428-434$.

Van Soest, P.J., Robertson, J.B., Lewis, B.A., 1991. Methods for dietary fiber, neutral detergent fiber, and nonstarch polysaccharides in relation to animal nutrition. J. Dairy Sci. 74, 3583-3597. http://dx.doi.org/10.3168/jds.S0022-0302(91)78551-2.

Williams, A.G., 1986. Rumen holotrich ciliate protozoa. Microbiol. Rev. 50, 25-49.

Yu, Z., Morrison, M., 2004. Improved extraction of PCR-quality community DNA from digesta and fecal samples. Biotechniques $36,808-813$. 